\title{
Effect of cavity shape, bond quality and volume on dentin bond strength
}

\author{
Hyo-Jin Lee', Jong-Soon Kim², Shin-Jae Lee ${ }^{2.3}$, Bum-Soon Lim², \\ Seung-Ho Baek ${ }^{12}$, Byeong-Hoon $\mathrm{Cho}^{12 *}$ \\ 'Dept. of Conservative Dentistry, 'Dental Research Institute, 'Dept. of Orthodontics, \\ 'Dept. of Dental Biomaterials, School of Dentistry', Seoul National University'
}

\section{ABSTRACT}

The aim of this study was to evaluate the effect of cavity shape, bond quality of bonding agent and volume of resin composite on shrinkage stress developed at the cavity floor. This was done by measuring the shear bond strength with respect to iris materials (cavity shape: adhesive-coated dentin as a high $\mathrm{C}$-factor and Teflon-coated metal as a low $\mathrm{C}$-factor), bonding agents (bond quality; Scotchbond ${ }^{\mathrm{TM}}$ Multi-purpose and Xeno ${ }^{\mathrm{B}} \mathrm{III}$ ) and iris hole diameters (volume; $1 \mathrm{~mm}$ or $3 \mathrm{~mm}$ in diameter $\times 1.5 \mathrm{~mm}$ in thickness). Ninety-six molars were randomly divided into 8 groups $(2 \times 2 \times 2$ experimental setup). In order to simulate a Class I cavity, shear bond strength was measured on the flat occlusal dentin surface with irises. The iris hole was filled with $\mathrm{Z250}$ restorative resin composite in a bulk-filling manner. The data was analyzed using three-way ANOVA and the Tukey test. Fracture mode analysis was also done. When the cavity had high $\mathrm{C}$-factor, good bond quality and large volume, the bond strength decreased significantly. The volume of resin composite restricted within the well-bonded cavity walls is also be suggested to be included in the concept of C-factor, as well as the cavity shape and bond quality. Since the bond quality and volume can exaggerate the effect of cavity shape on the shrinkage stress developed at the resin-dentin bond, resin composites must be filled in a method, which minimizes the volume that can increase the $\mathrm{C}$-factor. [J Kor Acad Cons Dent $30(6): 450-460,2005]$

Key words: C-factor, Cavity shape, Bond quality, Volume, Dentin bond strength, Polymerization shrinkage stress

- Received 2005.6.13., revised 2005.7.16., accepted 2005.7.27. -

\section{* Corresponding author: Byeong-Hoon Cho}

Department of Conservative Dentistry and Dental Research Institute, College of Dentistry, Seoul National University 28-2 Yeongeon-dong, Chongro-gu, Seoul, Korea, 110-749 Tel: 82-2-2072-3514 Fax: 82-2-764-3514 E-mail: chobh@snu.ac.kr

\section{INTRODUCTION}

The polymerization shrinkage stress in resin composite restoration has been studied as a function of cavity shape. Feilzer, et al ${ }^{\prime \prime}$ first described the effect of cavity shape on shrinkage stress as the configuration factor (C-factor), which was calculated from the ratio of unbonded to bonded sur-

※ This work was supported by a grant from the Ministry of Health and Welfare of Korea (Grant No. 03-PJ1PG1-CH09-0001). 
face area. Because the bond strength of the dentin bonding agent at that time was insufficient to resist the shrinkage stress of the resin composite, polymerization shrinkage of the resin composite lead to separation of the resin-dentin bond at the dentin wall of the cavity. Recently, bond strength has improved to values greater than the suggested shrinkage stress of $20 \mathrm{MPa}$ resulting from the polymerizing resin composite ${ }^{2)}$. However, the detrimental effect of the inherent shrinkage of polymerizing resin composite on dentin bond strength has still been investigated with respect to the $\mathrm{C}$-factor by comparing the bond strengths of resin composites filled in the cavities with different $\mathrm{C}$-factors, bonding agents, and various filling techniques ${ }^{3-5)}$.

It is generally accepted that the direction of shrinkage in a light-curing resin composite restoration depends on the cavity shape and bond quality $^{6.7)}$. In an in vitro study, Asmussen \& Peutzfeldt ${ }^{8\rangle}$ demonstrated that light-curing resin composites filled in a ring-shaped brass mold shrank towards the light source when the thickness of resin composite was less than that being cured in most clinical situations $(<2 \mathrm{~mm})$. However, when an adequate bond quality was obtained at the bottom wall as well as the lateral walls, the light-curing resin composite did not shrink toward the light source during polymerization $^{7-9)}$. Because the bulk of the resin composite shrank toward a certain point between the center of the bulk and the cavity floor, the shrinkage of the polymerizing resin composite still exerted stresses on the adhesive layer at the cavity floor ${ }^{9)}$. Moreover, even if the bonding agent is cured properly following the manufacturer's instruction, the initial strength of the adhesive layer is so poor that it cannot resist the shrinkage stress of the polymerizing resin composite. The shrinkage stress may result in cracks within the bonded complex during an early stage of the filling procedure $^{10)}$ and may lead to gap formation, marginal discoloration, postoperative sensitivity, and $\mathrm{sec}^{-}$ ondary caries ${ }^{11}$.

The bond strength at each wall within a cavity may be affected by the bond strength, named here as bond quality, of the bonding agent applied to the other walls within the cavity, as well as the ratio of bonded/unbonded area. This means that when defining the $\mathrm{C}$-factor, the bond quality at each wall should be simultaneously considered with the surface area of cavity walls. In addition to bond quality and surface area, the volume of resin composite may also be included in the concept of $\mathrm{C}$-factor. This is due to that larger amounts of resin composite will show a greater amount of volumetric shrinkage in an absolute dimension and accordingly will result in increased recession of a certain marginal part of the resin composite mass.

In this study, it was hypothesized that when resin composite was filled into a cavity, if the ratio of bonded/unbonded surface area was great, the cavity walls had already been bonded well and the volume of resin composite was large, increased shrinkage stresses would apply to the resin-dentin bond from the polymerizing resin composite and nominal shear bond strength values would decrease. The aim of this study was to evaluate the effect of cavity shape assumed by different wall materials, bond quality of the bonding agent and volume of the resin composite on the shrinkage stress developed at the cavity floor. This was done by measuring the shear bond strength with respect to iris materials (cavity shape), bonding agents (bond quality) and iris hole diameters (volume) using the iris method that simulates a Class I cavity.

\section{MATERIALS AND METHODS}

\section{Experimental Design}

Three variables, cavity shape, bond quality and volume, were selected for measuring the shear bond strength of a resin composite to the dentin at the cavity floor of a Class I restoration. To simulate the variable 'cavity shape', two types of irises were made of dentin and metal. The internal wall of the dentin iris hole was treated with the assigned bonding agent in order to obtain a Class I cavity with a high $\mathrm{C}$-factor, when the iris 
was put on a flat dentin surface treated with the same bonding agent (Figure 1). The internal wall of the metal iris hole was coated with Teflon in order to prevent bonding to the lateral walls. thereby achieving bonding on the flat dentin surface with a low $\mathrm{C}$-factor. To observe the variable 'bond quality', because the bond strength of fourth generation bonding systems were generally accepted to be higher than that of sixth generation systems ${ }^{122}$, Scotchbond Multi-Purpose (SBMP; $4^{\text {th }}$ generation total-etch bonding system, 3M ESPE, St. Paul, MN, USA) and Xeno III ( $6^{\text {th }}$ generation self-etch bonding system. Detrey/ Dentsply, Konstanz, Germany) were treated on the internal wall of the dentin iris hole and flat occlusal dentin surface on which the iris would be placed. In the case of metal iris, since the inter- nal wall of the iris hole was coated with Teflon, the polymerizing resin composite bonded only to the cavity floor. To test the variable 'volume', a hole of $1 \mathrm{~mm}$ or $3 \mathrm{~mm}$ in diameter was drilled at the center of $1.5 \mathrm{~mm}$ thick irises, so that the volume of the resin composites filled into the iris holes varied by nine fold. Thereby, a $2 \times 2 \times 2$ test design was constructed. In order to investigate the effect of these variables on shrinkage stress at the cavity floor, after treating the flat occlusal dentin with the assigned bonding agent, the iris whose internal wall was treated with the same bonding agent was placed on the treated dentin surface and resin composite (Filtek Z-250:3M ESPE) was filled into the iris hole in a bulk-filling method.

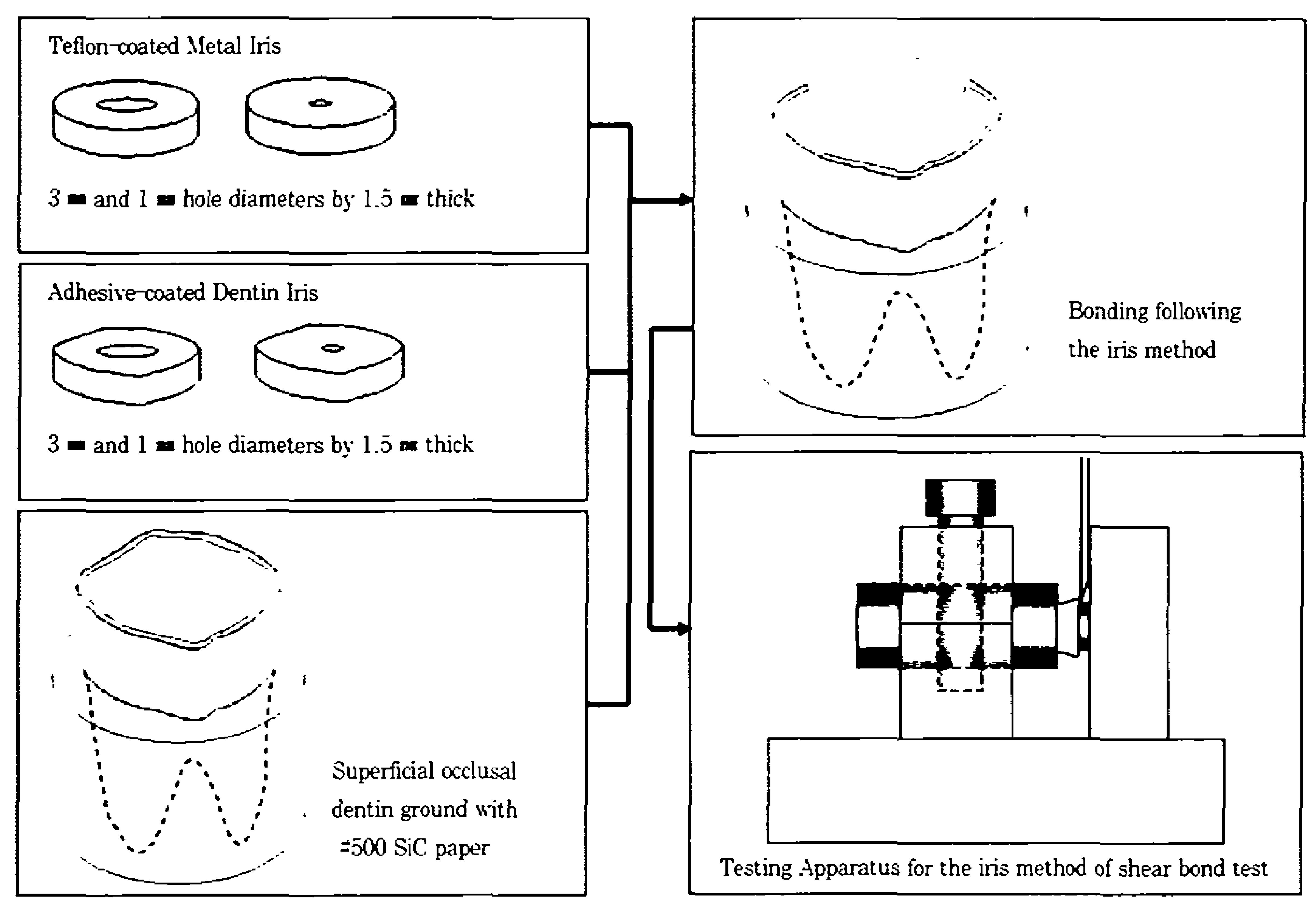

Figure 1. Schematic illustration of the experimental set-up. The metal and dentin irises having a hole of $1 \mathrm{~mm}$ or $3 \mathrm{~mm}$ in diameter and $1.5 \mathrm{~mm}$ in thickness were prepared. The internal wall of the metal iris was coated with Teflon and that of the dentin iris was treated with the assigned bonding agent. The irises were put on the flat occlusal dentin surface, which was also treated with the same bonding agent. and resin composite was filled into the hole. The shear bond strength was measured following the chisel-on-iris method. 


\section{Iris preparation}

The dentin iris was made by sectioning teeth into discs with a thickness of $1.50 \pm 0.08 \mathrm{~mm}$ with a low-speed diamond saw (ISOMET; Buehler Co., IL, USA) from the middle portion of the crown, trimming the lateral surface at a right angle to the sectioned surface, and drilling a hole of $1 \mathrm{~mm}$ or $3 \mathrm{~mm}$ in diameter. The sections were stored in distilled water at room temperature. Teflon tape, $0.14 \mathrm{~mm}$ thick, was punched to form a hole with the same diameter as the dentin iris and attached to the bottom surface of the dentin iris just before the bonding procedure.

The stainless-steel metal iris, $7 \mathrm{~mm}$ in diameter and $1.5 \mathrm{~mm}$ in thickness, with a hole of either $1 \mathrm{~mm}$ or $3 \mathrm{~mm}$ in diameter, was sandblasted, heat-treated, and spray-coated with Teflon (average thickness: $20 \mu \mathrm{m})$ on all surfaces including the internal surface of the hole, and were used as a mold for packing the resin composite.

\section{Bonding procedure}

Ninety-six caries-free human third molars were used in this study. After extraction, the teeth were debrided and refrigerated at $4^{\circ} \mathrm{C}$ in 0.5 mass fraction\% chloramine-T solutions for 24 hours. They were then stored in distilled water until needed. Within one month of extraction, they were embedded in a self-cure epoxy resin for use.
The teeth were sectioned using a low-speed diamond saw under water irrigation through the mid-crown to expose the superficial occlusal dentin. The exposed dentin surface was polished with 500 grit $\mathrm{SiC}$ paper. The prepared specimens were randomly divided into eight experimental groups $(2 \times 2 \times 2$ experimental setup). The assigned bonding agent was applied to the polished occlusal dentin surface and light-cured (Hilux ultra plus, Benlioglu Dental inc., Ankara, Turkey; Light intensity: $600 \mathrm{nW} / \mathrm{cm}^{2}$ ) according to the manufacturer's instructions (Table 1). In the case of dentin iris, prior to positioning the iris on the occlusal dentin surface, the internal surface of the iris hole was treated with the bonding agent and light-cured. The iris was pressed against the treated dentin surface using a holder. Filtek Z250 Universal Restorative (A2 shade) was filled into the iris hole in a bulk-filling manner and then light-cured for 20 seconds. The assembly was allowed to sit for an additional 4 minutes, and then immersed in distilled water at room temperature for 24 hours prior to testing.

Shear bond strength test and fracture surface analysis

The bonded assembly was loaded in a shear mode until fracture in a universal testing machine (Instron 4400, Instron Corp., Canton, MA, USA) at a crosshead speed of $1.0 \mathrm{~mm} / \mathrm{min}$ following the

Table 1. The adhesive systems and resin composite tested in this study and their application protocols

\begin{tabular}{|c|c|c|}
\hline $\begin{array}{l}\text { Scotchbond } \\
\text { Multi-Purpose }\end{array}$ & $\begin{array}{l}\text { etch with } 35 \mathrm{wt} \% \mathrm{H}_{3} \mathrm{PO}_{4} \text { for } 15 \mathrm{sec} \\
\text { rinse for } 15 \mathrm{sec} \\
\text { remove excess water with water-soaked tissue } \\
\text { apply primer and gently dry for } 5 \mathrm{sec} \\
\text { apply adhesive and light-cure for } 10 \mathrm{sec}\end{array}$ & $\begin{array}{c}\text { 3M ESPE } \\
\text { Dental Products }\end{array}$ \\
\hline Xeno ${ }^{\circledR}$ III & $\begin{array}{l}\text { mix liquid } A \text { and } B \\
\text { apply mixture with continuous scrubbing motion for } 20 \mathrm{sec} \\
\text { gentle air blow and light-cure for } 10 \mathrm{sec}\end{array}$ & DENSPLY \\
\hline $\begin{array}{l}\text { Filtek }^{\mathrm{TM}} \mathrm{Z} 250 \\
\text { Universal Restorative }\end{array}$ & light-cure for $20 \mathrm{sec}$ & $\begin{array}{c}\text { 3M ESPE } \\
\text { Dental Products }\end{array}$ \\
\hline
\end{tabular}


chisel-on-iris method ${ }^{13)}$. The bond strength data was analyzed using three-way ANOVA and the Tukey test to determine the interactions between the variables, i.e., the iris material (cavity shape), the bonding agent (bond quality), and the hole diameter (volume). All statistical analyses were conducted at a $95 \%$ confidence level using SigmaStat (Version 2.03; Jandel Scientific. Chicago, IL, USA).

After debonding, the failure mode of each specimen was determined and classified into failure at the top of the hybrid layer' or 'mixed failure' that accompanied partially cohesive fracture in the adhesive resin and resin composite under a stereomicroscope (SZ4045TR, Olympus Optical Co.. Tokyo, Japan). The failure mode patterns were verified using a scanning electron microscopy (SEM, JSM-840A: JEOL Ltd, Tokyo, Japan). The bond strength values obtained from the specimens that indicated cohesive failure in the dentin or resin composite were excluded from the data.

\section{RESULTS}

The power analysis revealed that our sample size was adequate. The mean shear bond strength and standard deviations for the three variables (cavity shape, bond quality and volume) are shown in Table 2. Three-way ANOVA showed that significant differences were observed for each variable $(p<0.001$, Table 2$)$. When shear bond strengths were measured with dentin irises (high $\mathrm{C}$-factor). they were significantly lower than those measured with metal irises (low C-factor). When SBMP was used, shear bond strengths were significantly higher than those bonded with Xeno III. When the volume of resin composite was large ( $3 \mathrm{~mm}$ hole), bond strength decreased significantly.

Table 2 Shear bond strengths measured using the iris method with respect to iris materials, bonding agents and iris hole diameters (SBS: mean $\pm S D, N=12$, unit: $\mathrm{MP}_{2}$ )

\begin{tabular}{|c|c|c|c|c|c|c|}
\hline \multirow{2}{*}{$\begin{array}{c}\text { Iris } \\
\text { material }^{\dagger}\end{array}$} & \multirow{2}{*}{$\begin{array}{l}\text { Diameter } \\
\text { of Iris hole }\end{array}$} & \multirow{2}{*}{$\mathrm{C}-$ factor $^{*}$} & \multicolumn{2}{|c|}{ Bonding agent $^{\dagger}$} & \multirow{2}{*}{\multicolumn{2}{|c|}{$\begin{array}{c}\text { Results of } \\
\text { Three-Way ANOVA }\end{array}$}} \\
\hline & & & SBMP & Xeno III & & \\
\hline \multirow{2}{*}{ Metal $^{9}$} & $1 \mathrm{~mm}$ & 0.2 & $41.8 \pm 7.0$ & $23.0 \pm 8.5$ & $\begin{array}{l}\text { Main Effect } \\
\text { metal iris }<\text { dentin iris }\end{array}$ & $p<0.001$ \\
\hline & $3 \mathrm{~mm}$ & 0.43 & $35.8 \pm 10.3$ & $18.9 \pm 6.4$ & $\begin{array}{l}\text { Xeno III }<\text { SBM.PP } \\
1 \mathrm{~mm}<3 \mathrm{~mm}\end{array}$ & $\begin{array}{l}p<0.001 \\
p<0.001\end{array}$ \\
\hline \multirow{2}{*}{ Dentin $^{5}$} & $1 \mathrm{~mm}$ & 5.0 & $32.6 \pm 13.4$ & $22.9 \pm 8.9$ & $\begin{array}{l}\text { Interaction effects } \\
\quad \text { iris material }{ }^{*} \text { bonding agent }\end{array}$ & $p=0.003$ \\
\hline & $3 \mathrm{~mm}$ & 2.33 & $15.4 \pm 7.6$ & $10.7 \pm 3.1$ & $\begin{array}{l}\text { iris material }{ }^{*} \text { diameter } \\
\text { diameter }{ }^{*} \text { bonding agent }\end{array}$ & $\begin{array}{l}p=0.00 T \\
p=0.336\end{array}$ \\
\hline
\end{tabular}

* Each iris had a hole of $1 \mathrm{~mm}$ or $3 \mathrm{~mm}$ in diameter and $1.5 \mathrm{~mm}$ in height for reproducing a Class I cavity.

$\dagger$ The column titles 'iris material, diameter of iris hole and bonding agent' designate the variables of 'cavity' shape, bond quality and volume , respectively.

\# The C-factors were calculated from the ratio of bonded/unbonded surface area.

$\S$ SBMP: Scotchbond ${ }^{\mathrm{TN}}$ Multi-purpose.

I The internal wall of the metal iris was coated with Teflon in order to prevent bonding to the lateral walls and thereby achieving bonding only on the flat dentin surface with a low $\mathrm{C}$-factor. However, the internal wall of the dentin iris was treated with the assigned bonding agent in order to obtain a Class I cavity with a high Cfactor upon placing the iris on the flat dentin surface treated with the same bonding agent. 
There were statistically significant interactions between the variables of cavity shape (iris material) and bond quality (bonding agent), and between cavity shape and volume (iris hole diameter) ( $p=0.003$ and $p=0.007$, respectively, Table 2): On the other hand, the interaction between the variables of bond quality and volume was not found $(p=0.336)$. The two significant interaction terms indicated that although the effect of bond quality on shear bond strength was not dependent upon the volume, the effect of cavity shape on bond strength was dependent upon the bond quality and volume of resin composite.

On the fracture surfaces, there were two main features, the plain detached area, which was parallel with the ground occlusal dentin surface, and the inclined fractured area, in which the failure plane meandered through more than one material (Figure 2). When most of the fractured surface area was plain detached area, it was classified as 'Failure at the top of the hybrid layer', because most of the surfaces were covered with resinous material. However, if fracture fragments of the adhesive layer or resin composite were left on the dentin side, the fractures were classified as 'Mixed failure' (Table 3 and Figure 2). The incidences of 'failure at the top of the hybrid layer' and 'mixed failure' were nearly the same between the metal iris and dentin iris. Xeno III showed a higher incidence of failure at the top of the hybrid layer' than SBMP. The irises having a 3 $\mathrm{mm}$ hole presented a much higher incidence of 'failure at the top of the hybrid layer' than those having a $1 \mathrm{~mm}$ hole (Figure 3). Only 3 specimens in the group bonded with SBMP using the metal iris with a $3 \mathrm{~mm}$ hole demonstrated complete cohesive failure in the dentin and only 1 in the group bonded with SBMP with $3 \mathrm{~mm}$ hole dentin irises demonstrated cohesive failure in the resin $\mathrm{com}^{-}$ posite. These specimens were excluded from the bond strength data (Table 3).

Table 3. Failure modes of fractured specimens resulting from shear bond strength tests using the iris method with respect to iris materials, bonding agents and iris hole diameters

\begin{tabular}{|c|c|c|c|c|c|c|}
\hline \multirow{2}{*}{$\begin{array}{c}\text { Iris } \\
\text { material }\end{array}$} & \multirow{2}{*}{$\begin{array}{c}\text { Bonding } \\
\text { agent }\end{array}$} & \multirow{2}{*}{$\begin{array}{l}\text { Diameter } \\
\text { of iris hole }\end{array}$} & \multicolumn{3}{|c|}{ Failure modes } & \multirow{2}{*}{ Composite cohesive } \\
\hline & & & $\begin{array}{l}\text { Dentin cohesive } \\
\text { failure }\end{array}$ & $\begin{array}{l}\text { Failure at the } \\
\text { top of hybrid layer }\end{array}$ & Mixed failure & \\
\hline \multirow{4}{*}{ Metal } & $\mathrm{SBMP}^{\dagger}$ & $1 \mathrm{~mm}$ & & 2 & 10 & \\
\hline & & $3 \mathrm{~mm}$ & $3^{\ddagger}$ & 9 & 3 & \\
\hline & Xeno III & $1 \mathrm{~mm}$ & & 6 & 6 & \\
\hline & & $3 \mathrm{~mm}$ & & 9 & 3 & \\
\hline \multirow{4}{*}{ Dentin } & $\mathrm{SBMP}^{\dagger}$ & $1 \mathrm{~mm}$ & & 2 & $\overline{10}$ & \\
\hline & & $3 \mathrm{~mm}$ & & 8 & 4 & $1^{*}$ \\
\hline & Xeno III & $1 \mathrm{~mm}$ & & 5 & 7 & \\
\hline & & $3 \mathrm{~mm}$ & & 9 & 3 & \\
\hline
\end{tabular}

$\dagger$ SBMP: Scotchbond ${ }^{\mathrm{TM}}$ Multi-purpose.

\# Bond strength values of the specimens showing completely cohesive failure in dentin or resin composite were excluded from the data.

$\S$ When most of the fractured surface area was a detached plain surface following the ground occlusal dentin surface, it was classified as 'Failure at the top of the hybrid layer', because most of the surfaces were covered with resinous material. However, if fragments fractured from the adhesive layer or resin composite were left on the dentin side, the fractures were classified as 'Mixed failure'. 

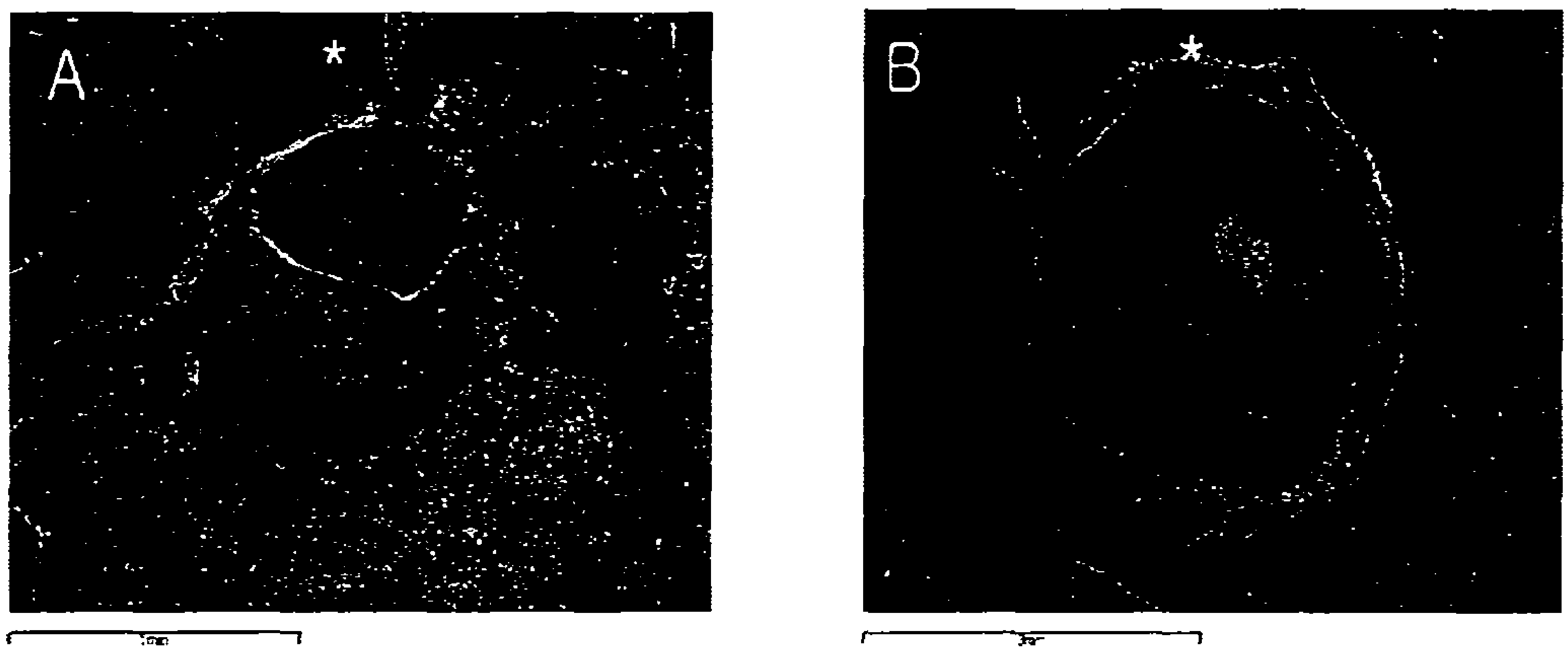

Figure 2 Scanning electron micrograph of the failure surfaces.

A. Mixed failure. Fracture fragments of the adhesive layer were observed simultaneously with the detached plain surface at the top of the hybrid layer. The specimen was tested with the dentin iris having a $1 \mathrm{~mm}$ hole and SBMP $(\times 20)$.

B. Typical failure at the top of the hybrid layer observed in the specimen tested with the metal iris having a $3 \mathrm{~mm}$ iris hole and Xeno III (magnification: $\times 20$ ).

*: the direction from which the load was applied.

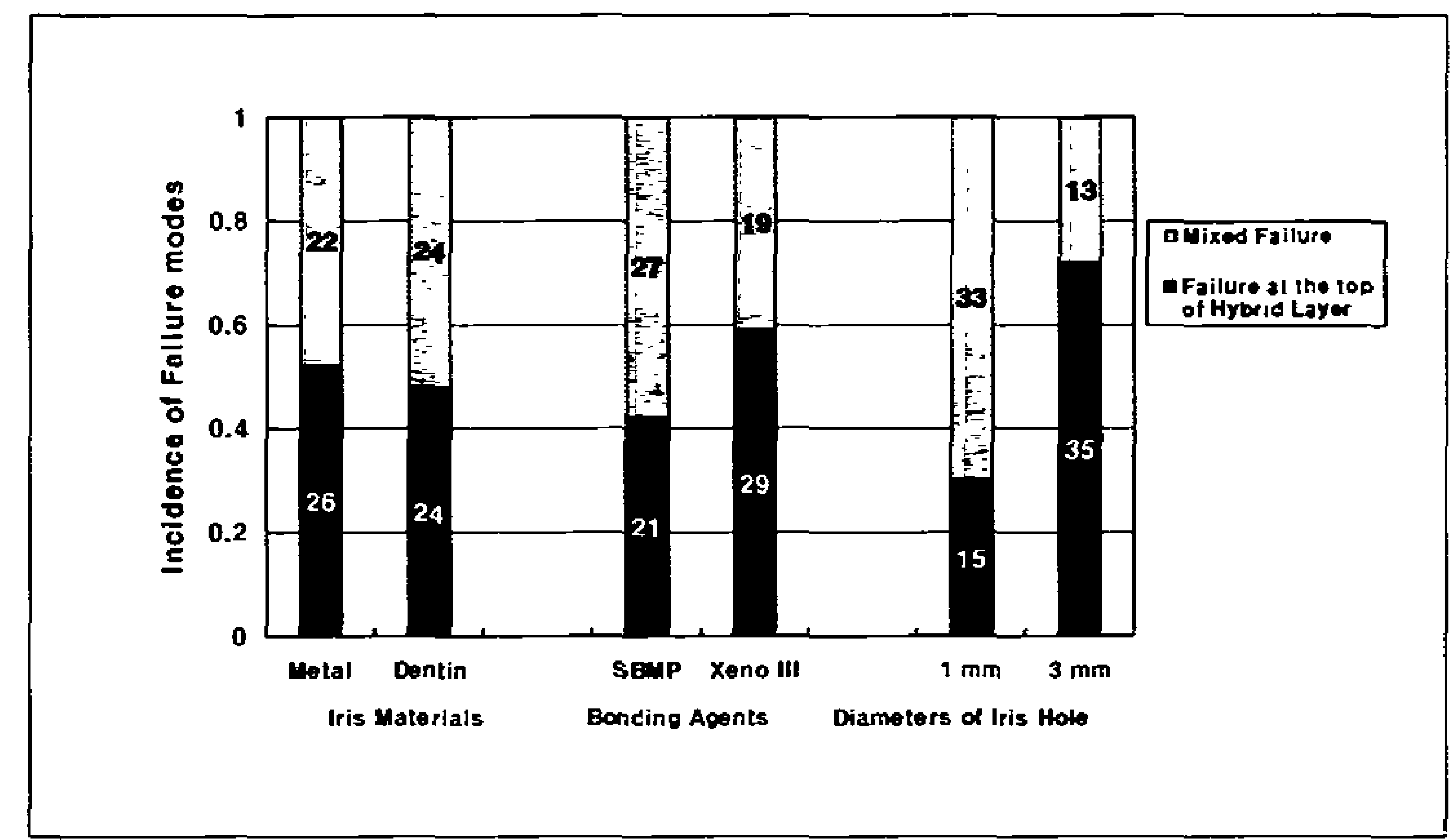

Figure 3. Incidence of failure modes with respect to iris materials (cavity shape), bonding agents (bond quality) and diameters of iris hole (volume). The numbers in the bars are those of the specimens showing 'failure at the top of the hybrid layer' or 'mixed failure' .

\section{DISCUSSION}

The bond strength values were used to compare the quality and efficacy of the dental adhesive products. The microtensile bond strength test has become accepted as the most reliable method. However, due to the relative simplicity in preparing the test specimens and the ease in fabricating the test equipment, shear bond strength tests have been used frequently to evaluate dentin bonding systems. Along with the improvement in bond strength of the current generation dentin bonding agents, cohesive failure in dentin during shear bond strength tests was observed more frequently ${ }^{1+1}$. However, rather than improvement in the material properties, the test mechanics of the shear test set-up, such as loading condition ${ }^{15-17}$ and small changes in the geometric arrange- 
ment ${ }^{18.19)}$, was suggested to cause the variations in strength values and cohesive fracture in dentin.

Due to such drawbacks, test methods measuring the shear bond strength of bonding agents evolved to improve the test mechanics ${ }^{13.20)}$. The chisel-oniris method was suggested to be simple and to avoid the extraneously introduced failure modes, such as cohesive fracture in dentin ${ }^{13)}$. In this study, only 3 specimens tested with the iris method showed dentin cohesive failures and only 1 specimen failed within the resin composite. They were excluded from the data (Table 3), due to being regarded as representing the cohesive strength of the dentin and resin composite themselves, respectively, not the adhesive bond strength. Therefore, the iris method using the metal iris appeared to have advantages in reducing the stress concentration, thereby preventing the deviation of fracture propagation from the adhesive plane, and thus measuring a more approximate 'true shear bond strength' over other shear test methods ${ }^{13)}$.

The iris method has another unique advantage in reproducing a Class I cavity and might represent clinical situations more similarly than the conventional shear test using a composite cylinder. In this study, the internal surface of the iris hole was either a Teflon-coated metal or an adhesive-treated dentin. The adhesive-treated internal wall of the dentin iris simulated the lateral wall of a Class I cavity, which had a high $\mathrm{C}$-factor. On the other hand, in order to simulate a situation having a low $\mathrm{C}$-factor, the internal wall of the metal iris was coated with Teflon so that the resin composite could bond only to the flat dentinal surface of cavity floor. Under the specific condition of this study, the shear bond strengths measured with dentin irises were lower than those measured with metal irises $(p<0.001$, Table 2). The result was in agreement with previous reports showing that the bond strength of a resin composite filled into a cavity was lower than that bonded to a flat dentin surface ${ }^{4.5}$. Therefore, the shear bond strength must be affected by the variable 'cavity shape' that was reproduced by the different iris materials. The adhesive-treated internal wall of the dentin iris must have induced a higher level of stress at the resin-dentin bonded interface of the cavity floor than the unbonded wall of the Teflon-coated metal iris. The contraction stress from polymerizing resin composite in a cylindrical Class I cavity represented by dentin iris might have affected the shear bond strength. This stress was suggested to induce contraction gaps $^{9}$, which influenced the marginal adapta$\operatorname{tion}^{6.11 .21}$. The lower bond strength values might represent the resin-dentin bond strength at the interface within an actual cavity.

Besides the well-known C-factor that is dependent upon cavity geometry, contraction stress was affected by whether the internal surface of the mold for packing the resin composite was Tefloncoated or roughened ${ }^{6}$. The experimental setup used in this study had the same cylindrical configuration with their ring mold. However, rather than the roughened internal surface of the ring mold, two bonding agents were used to evaluate the effect of bond quality on the shrinkage stress of the resin composite filled into the iris. Confirming the general agreement that the bond strength of the fourth generation dentin bonding system is higher than that of the sixth generation ${ }^{12)}$, the shear bond strength of SBMP was higher than that of Xeno III ( $p<0.001$, Table 2 ). Therefore, the selection of two bonding agents to compare the effect of bond quality on the shrinkage stress was appropriate. The interaction between the variables 'cavity shape' and 'bond quality' was statistically significant $(p=0.003$, Table 2), indicating that the effect of different cavity shapes on bond strength values was dependent upon different types of bonding agents.

Since the C-factor is estimated by definition from the ratio of bonded to unbonded surface area, it can vary with different diameters and heights even in a Class I cavity. In this study, the height of the iris hole was fixed to the dimension of $1.5 \mathrm{~mm}$ for ease of preparing the dentin disc. When the diameters of the iris holes increased from $1 \mathrm{~mm}$ to $3 \mathrm{~mm}$, the C-factors of the dentin irises decreased from 5.0 to 2.33 , but those of the metal irises slightly increased from 
0.2 to 0.43 (Table 2). In addition to the originally defined $\mathrm{C}$-factor, which affected the bond strength as discussed in the previous sections, three-way ANOVA revealed that the bond strengths measured with this irises having a $3 \mathrm{~mm}$ hole were significantly lower than those measured with the irises having a $1 \mathrm{~mm}$ hole $(\mathrm{p}<0.001$. Table 2$)$ and the interaction between the variables cavity shape' (iris material) and 'volume' (iris hole diameter) was statistically significant ( $p=0.007$. Table 2). Therefore, the variable of 'volume' determined by the diameter of the iris hole must have affected the bond strength measurements. There was no statistically significant interaction between the variables of 'bond quality' and 'volume' ( $p=0.336$, Table 2$)$.

In this study, the shear bond strength measured with the irises having a $3 \mathrm{~mm}$ hole was lower than that measured with the irises having a $1 \mathrm{~mm}$ hole. This could be explained by the general acceptance that a smaller bonded area would obtain higher bond strength. A smaller bonded area contains fewer defects compared to a larger one, thereby increasing the bond strength ${ }^{221}$. This interpretation agreed with the results recorded for the dentin iris (Table 2). However, in the case of the metal iris, the difference in the bond strengths measured with irises of different hole diameters was not so apparent (Table 2). The comparison suggested that the changes in bond strength according to the diameter couldn $t$ be understood only by considering bonded area. The different iris materials must have affected the result as well. The absolute amount of shrinkage, which resulted from the volume of resin composite affected by the $\mathrm{C}$-factor, could be suggested as a factor influencing the bond strength in the dentin iris. Contrary to the dentin iris, since there were no bonds between the resin composite and the Teflon-coated internal wall of the metal iris, the direction of shrinkage was mainly toward the cavity floor. The volume of resin composite restricted within the bonded lateral wall was so small in the metal iris that it might have a negligible effect on the shrinkage stresses exerted on the resin-dentin bond at the cavity floor. Although the increase in the hole diameter of metal iris resulted in a slight increase in $\mathrm{C}$-factor, the increase in bonded area did not decrease the bond strength not so much as the dentin iris (Table 2). Therefore, the change in the 'diameter' of the iris hole can be transformed to the 'volume' that was restricted within the bonded wall and thus affected the $\mathrm{C}$-factor.

The transformation of the variable of 'diameter' to 'volume' was confirmed by fracture surface analysis. In order to simplify the classification of failure modes, the observed fracture surfaces were divided into the plain detached area, which was parallel with the ground occlusal dentin surface. and the inclined fractured area, in which the failure plane meandered through more than one material (Figure 2). When most of the fractured surface was plain detached area, it was classified as failure at the top of the hybrid layer', because most of the surfaces were covered with resinous material. However, if fracture fragments of the adhesive layer or resin composite were left on the dentin side, the fractures were classified as 'mixed failure' (Table 3 and Figure 2). The term 'mixed' was used in this study for the features, in which, regardless of fracture initiation site, fractures propagated through different materials. Accordingly, in a mixed failure, the fractures at the dentin surface covered with resinous material (hybrid layer), across or within the adhesive resin layer and into the resin composite, could be found simultaneously with various combinations and proportions.

The incidences of failure at the top of the hybrid layer' and 'mixed failure' were nearly the same between the metal iris and dentin iris (Figure 3). The variable of 'cavity shape' failed to show a difference in the incidence between the two failure modes. However, the variables of 'bond quality' and 'volume' showed different incidences of the two failure modes (Figure 3). The failure analysis suggested that the groups showing low bond strength (Xeno III and $3 \mathrm{~mm}$ hole) result in a higher incidence of failure at the top of the hybrid layer than the groups showing high bond strength (SBMP and $1 \mathrm{~mm}$ hole. Table 2 and Figure 3). Since the failure at the top of the hybrid layer' was mainly composed of plain 
detached area, it could originate from early debonding between the hybrid layer and adhesive layer, which was developed by the contraction stress from the polymerizing resin composite at an early stage of the bonding procedure ${ }^{10.23)}$. It is well accepted that increased bonded area increases the inherent defect and as a result, decreases bond strength. However, this describes the situation at the time of load application. The inherent defects may change the path of crack propagation into different material and induce mixed failure. The high incidence of failure at the top of the hybrid layer' and low bond strength in the groups using a $3 \mathrm{~mm}$ hole in this study may have resulted from early debonding caused by large volumetric shrinkage of the polymerizing resin composite (Table 2 and Figure 3). Therefore, the dimension 'diameter' can be designated as the variable 'volume', rather than 'bonded area'.

\section{CONCLUSIONS}

The volume of resin composite restricted within the well-bonded cavity walls, as well as the cavity shape and bond quality, might also be included in the concept of $\mathrm{C}$-factor. Since the bond quality and volume can exaggerate the effect of cavity shape on the shrinkage stress developed at the resin-dentin bond, resin composites must be filled in a method minimizing the volume that can increase the $\mathrm{C}$-factor, even with bonding agents having good bond quality.

\section{References}

1. Feilzer AJ, de GEE AF, Davidson CL. Setting stress in composite resin in relation to configuration of the restoration. J Dent Res 66:1636-1639, 1987.

2. Davidson CL, de Gee AJ, Feilzer A. The competition between the composite-dentin bond strength and the polymerization contraction stress. J Dent Res 63:13961399, 1984

3. Armstrong SR, Keller JC, Boyer DB. The influence of water storage and $\mathrm{C}$-factor on the dentin-resin $\mathrm{com}^{-}$ posite microtensile bond strength and debond pathway utilizing a filled and unfilled adhesive resin. Dent Mater 17:268-276, 2001.

4. Nikaido T, Kunzelmann KH, Chen H, Ogata M, Harada N, Yamaguchi S, Cox CF, Hickel R, Tagami J. Evaluation of thermal cycling and mechanical loading on bond strength of a self-etching primer system to dentin. Dent Mater 18:269-275, 2002.

5. Nikolaenko SA, Lohbauer U, Roggendorf M, Petschelt A, Dasch W, Frankenberger R. Influence of c-factor and layering technique on microtensile bond strength to dentin. Dent Mater 20:579-585, 2004.

6. Uno S, Shimokobe H. Contraction stress and marginal adaptation of composite restorations in dentinal cavity. Dent Mater J 13:19-24, 1994.

7. Versluis A, Tantbirojn D, Douglas WH. Do dental composites always shrink toward the light? $J$ Dent Res 77:1435-1445, 1998.

8. Asmussen E, Peutzfeldt A. Direction of shrinkage of light-curing resin composites. Acta Odontol Scnad 57:310-315, 1999.

9. Cho BH, Dickens SH, Bae JH, Chang CG, Son HH, Um CM. Effect of interfacial bond quality on the direction of polymerization shrinkage flow in resin composite restorations. Oper Dent 27:297-304, 2002.

10. Dickens $\mathrm{SH}$, Cho $\mathrm{BH}$. Interpretation of bond failure through conversion and residual solvent measurements and Weibull analyses of flexural and microtensile bond strengths of bonding agents. Dent Mater 21(4):354364, 2005.

11. Peutzfeldt A, Asmussen E. Determinants of in vitro gap formation of resin composites. J Dent 32:109-115, 2004.

12. Inoue S, Vargas MA, Abe Y, Yoshida Y, Lambrechts P, Vanherle G, Sano H, van Meerbeeek B. Microtensile bond strength of eleven contemporary adhesives to dentin. $J$ Adhes Dent 3:237-245, 2001.

13. Dickens SH, Milos MF. Relationship of dentin shear bond strengths to different laboratory test designs. Am $J$ Dent 15:185-192, 2002

14. Oilo G, Austrheim E. In vitro quality testing of dentin adhesives. Acta Odontol Scand 51:263-269, 1993.

15. Della Bona A, van Noort R. Shear vs. tensile bond strength of resin composite bonded to ceramic. $J$ Dent Res 74:1591-1596, 1995

16. DeHoff PH, Anusavice KJ, Wang Z. Three-dimensional finite element analysis of the shear bond test. Dent Mater 11:126-131, 1995.

17. Versluis A, Tantbirojn D, Douglas WH. Why do shear bond tests pull out dentin? J Dent Res 76:1298-1307, 1997.

18. Van Noort R, Cardew G, Howard IC, Noroozi S. The effect of local interfacial geometry on the measurement of the tensile bond strength to dentin. $J$ Dent Res $70: 889-893,1991$

19. Kitasako $\mathrm{Y}$, Burrow MF, Nikaido T, Harada N Inokoshi S, Yamada T, Takatsu T. Shear and tensile bond testing for resin cement evaluation. Dent Mater 11:298-304, 1995

20. Watanabe LG, Marshall GW, Marshall SJ. Dentin sher strength: Effects of tubule orientation and intratooth location. Dent Mater 12:109-115, 1996.

21. Yoshikawa T, Burrow MF, Tagami J. The effects of bonding system and light curing method on reducing stress of different $\mathrm{C}$-factor cavities. $J$ Adhesive Dent 3:177-183, 2001

22. Sano H, Shono T, Sonoda H, Takatsu T, Ciucchi B, Carvalho R, Pashley DH. Relationship between surface area for adhesion and tensile bond strength-evaluation of a micro-tensile bond test. Dent Mater 10:236-40, 1994.

23. Cho BH, Dickens SH. Effects of the acetone content of single solution dentin bonding agents on the adhesive layer thickness and the microtensile bond strength Dent Mater 20:107-115, 2004. 


\title{
국문초록
}

와동의 형태, 접착층의 성숙도, 및 와동의 부피가 상아질 접착력에 미치는 영향

\author{
이효진 ${ }^{1}$ 김종순 ${ }^{1.2} \cdot$ 이신재 ${ }^{2.3} \cdot$ 임범순 ${ }^{2.4} \cdot$ 백승호 ${ }^{1.2} \cdot$ 조병훈 ${ }^{1.2 *}$
}

${ }^{1}$ 서울대학교 치과대학 치과보존학교실, ${ }^{2}$ 치학연구소, ${ }^{3}$ 교정학교실, ${ }^{1}$ 치과생체재료학교실

본 연구에서는 복합레진의 중합수축시 와동의 형태, 접착층의 성숙도, 및 와동의 부피가 와동저의 접착면에 발생 되는 중합수축응력에 미치는 영향을 평가하였다. 1 급 와동 충전시의 응력발생을 모방하기 위해. 98 개의 대구치를 $2 \times 2 \times 2$ 실험군에 무작위로 분배하고 교합면 상아질을 평탄하게 연마한 후, 복합레진 충전을 위한 몰드의 역할 을 할 수 있는 구멍을 가진 iris를 올려놓고 복합레진을 bulk-filling법으로 충전하였다. 각각의 변수로서 와동 형태 에 관하여는 iris 재질 (접착제를 도포한 상아질 iris: 높은 C-factor, Teflon 처리된 금속 iris: 낮은 C-factor), 접착층의 성숙도에 관하여는 2종의 접착제 (Scotchbond Multi-purpose와 Xeno III), 와동의 부피에 관하여는 iris내 구멍의 직경 (직경 1 또는 $3 \mathrm{~mm} \times$ 높이 $1.5 \mathrm{~mm}$ )을 달리하여 전단접착강도를 측정하였다. 와동의 C-factor 가 클수록, 접착층의 성숙도가 우수할수록 그리고 부피가 클수록 접착력은 유의하게 감소하였다. 복합레진이 중합 될 때, 와동의 형태적 제한에 따라 레진-상아질 접착계면에 발생되는 중합수축응력은 접착이 우수할수록 복합레진 의 부피가 클수록 증가되므로, C-factor를 정의할 때 와동의 형태뿐 아니라, 접착층의 성숙도와 복합레진의 부피도 함께 고려되어야 된다.

주요어: C-factor, 와동형태, 접착층의 성숙도, 와동의 부피, 상아질 접착력, 중합수축응력 